\title{
The Future of Banking System and Economic Development in Nigeria
}

\author{
Olu Ajakaiye and M. Adetunji Babatunde
}

\begin{abstract}
This study examined the future of banking system and economic development in Nigeria in the context of the demand-following hypothesis. Although, the Nigerian economy has witnessed steady growth, the productive base of the economy is narrow. This therefore requires that banks must engage in an effective financial intermediation process to aid the transformation of the real sector as an engine of growth. However, while the deposits mobilized and assets base of the commercial banks has increased in leap and bounds, the real sector access to credit is on the decline. Rather, the bulk of the funds are invested on government short term securities given their risk-free characteristics which reflect the lazy bank syndrome. Prohibitively high cost of credit and existence of hidden charges also inhibit real sector access to commercial banks loan. Hence, to reconnect the banking system with the real sector, there is a need to discourage armchair banking business model and encourage supportive banking business model, lending and secure appropriate maturity profile of loans to the real sectors, promote modified collateral bank lending model, and encourage specialization of bank branches. These are expected to aid the growth of the real sector and fast track the process of economic development in Nigeria.
\end{abstract}

Keywords: Banks, Savings, Loans, Real Sector, Development

\section{Introduction}

Banks play a crucial role in economic development. However, the impact of the banking system on the rest of the economy depends on how it mobilizes savings, allocates the savings, monitors the use of the funds by firms and individuals, pools and diversifies risk, including liquidity risk, and eases the exchange of goods and services. When the banking system performs well, it tends to promote growth and expand economic opportunities. For example, when banks screen borrowers effectively and identify firms with the most promising prospects, it represents the first step in boosting productivity growth. When banking institutions mobilize savings from disparate households to invest in these promising projects, this represents a second crucial step in fostering growth. When banking institutions monitor the use of investments and scrutinize their managerial performance, this is another essential ingredient in boosting the operational efficiency of corporations, reducing waste and fraud, and spurring economic growth. In addition, when the banking systems lower transaction costs, this 
enhances competitiveness and specialization, which are fundamental inputs into technological innovation and economic growth.

On the contrary, when financial systems perform poorly, they tend to hinder economic growth and curtail economic opportunities. For example, if the banking system simply mobilizes funds with one hand and passes them along to cronies, the wealthy, and the politically connected or invest it on instruments that do not have bearing on the performance of the real sector with the other hand, this produces a less efficient allocation of resources, implying slower economic growth. If the banking institutions fail to exert sound corporate governance, this makes it easier for managers to pursue projects that benefit themselves rather than the firm and the overall economy. Thus, the traditional role of banks consists of financial intermediation, provision of an efficient payments system and serving as conduit for the implementation of monetary policies. If these functions are efficiently carried out, the economy would be able to mobilize meaningful level of savings and channel these funds in an efficient and effective manner to influence economic growth. Banking system therefore functions as the economy's central nervous system, choosing where to allocate resources.

The Nigerian banking sub-sector has witnessed significant changes in terms of structure (ownership and type), size or number of banks, corporate value and volume of transactions in the 53 years since independence. The total assets of Nigerian banks increased from M82.96billion in 1990 to $£ J 71.25$ trillion in 2010. This is an increase of about 859 -folds. Credit to the private sector also increased from M33.55billion in 1990 to J410.16trillion in 2010, an increase of about 303-folds. Equally, the number of commercial bank branches in Nigeria increased from 3,231 in 2006 to 5,807 in 2010, while the capital base of the commercial banks also increased substantially. Indeed, much of the economies of scale are the result of consolidation supported by new (or better use of existing) technologies. This has allowed banks to reduce significantly their operating costs. These mainly take the fonns of ATM, online bill paying, the point of sales terminal (POS) and recently, the use of mobile phones-based transactions. It was estimated that Nigeria has about 30 million ATM card holders who conduct over 100 million transactions on the machines every month. Equally, Nigeria's 24 banks operate over 9,000 ATM machines across the country (Ayo, et al, 2010). These are some of the pieces of evidence that the Nigerian banking sub-sector has grown in size and sophistication over time.

These developments were therefore expected to reflect in the development of the real sector in Nigeria to foster economic growth. However, it remains a puzzle that the banking sector still has limited contribution to the real sector of the economy. These have been attributed to the dwindling allocation of funds by commercial banks to the real sector, high lending rate, the diverging spread between deposit rate and lending rate, perennial bank distress syndrome, substantial components of banks' total assets that do not have direct link with the real sector, perceived inherent risk in the real sector and the type of banking initiatives adopted to stimulate the performance of the real 
sector. For example, in a national survey, it was reported that over $80 \%$ Nigerian enterprises rank poor access to finance as the most difficult problem they face far ahead of other constraints such as poor infrastructure and government regulations (NBS-SMEDAN. 2012). Corroborating this finding, Shittu (2012) noted that credit to the private sector has no significant impact on economic growth in Nigeria. Further, Afangideh (nd) documents that bank lending to the Nigerian agriculture sector even has a negative impact on the sector's output growth.

The future of banking with respect to its contribution to economic development in Nigeria will largely be influenced by the manner in which the effective and efficient allocation of credit to the real sector is achieved. The real issue at stake is not the importance of cyberspace revolution and innovations rather the more important strategic issue for the Nigerian banking system is to restrategize on its core intermediation functions to foster economic development.

The kernel of this paper is to therefore examine the current state of play and the future of banking in Nigeria from the perspective of economic development. The aim is to situate the discussion in the context of the challenges and prospects of a future banking system promoting economic development in Nigeria. Following this introductory section, section two discusses the evolution of the Nigerian banking sector with respect to institutional development and structural changes, while section three highlights the role of banks in economic development. Section four articulates how the future banking system must be strengthened to promote economic development in Nigeria. Section five concludes.

\section{The Structure of the Nigerian Economy: Stylized Facts}

In theory, the relevance of the banking sector in economic development of Nigeria can be found within the context of the supply leading and the demand following hypothesis. The theoretical benchmark of the early studies on the relationship between finance and economic growth may be traceable to Schumpeter (1934), Mckinnon (1937) and Shaw (1973). The studies argued that the relationships may be summarised under four hypotheses.

First, the supply-leading hypothesis postulates that the direction of causality flows from financial development to economic growth. In a world without frictions caused by transaction, information and monitoring costs, no financial intermediaries are needed. If those costs are sufficiently high, no exchanges among economic agents will take place. The need to reduce those costs for exchanges to take place has led to the emergence of financial institutions and markets constituting the financial sector. A well-developed financial sector provides critical services to reduce those costs and thus to increase the efficiency of intermediation. It mobilises savings, identifies and funds good business projects, monitors the performance of managers, facilitates trading and the diversification of risks, and fosters exchange of goods and services. These services result in a more 
efficient allocation of resources, a more rapid accumulation of physical and human capital. and faster technological innovation, thus inducing faster long-term econoguc growth (Acaravci,etal.2009).

On the contrary, the demand-following hypothesis postulates that economic growth leads to financial development. The development of the real economy induces increased demand for financial services, which in turn, generate the introduction of new financial institutions and markets to satisfy that increased demand for financial services. Also, the bi-directional causality hypothesis is a combination of the supply-leading and demand following hypotheses. It postulates that financial deepening and economic growth are mutually or bi-directionally causal. Financial deepening gradually induces economic growth and this, in turn, causes feedback and induces further financial deepening. Fourth, the independent hypothesis postulates that financial deepening and economic growth are causally independent (Acaravci, et al. 2009).

The demand following hypothesis appeared to be the most relevant in the case of Nigeria. This is because economic growth has been on a steady increase in the last eight years. The GDP growth rate in Nigeria averaged 6.80 percent between 2005 and 2013, reaching an all-time high of 8.60 Percent in the fourth quarter of 2010 and a record low of $4.50 \%$ in the first quarter of 2009 due to the global financial crisis. The growth rate increased from $6.66 \%$ in 2012 to $7.41 \%$ in 2013 . In addition, the Nigerian economy is ranked 26th in the world in terms of GDP (nominal: 30th in 2013 before rebasing, 40th in $2005,52 \mathrm{nd}$ in 2000), and is the largest economy in Africa (based on rebased figures announced in April 2014). As a result of the statistical revision, Nigeria's GDP for 2013, is now N80.2 trillion (US\$509.9 billion). This is an increase of about $89 \%$ based on the old GDP estimates for 2013 which was N42.4 trillion (or US\$269.5 billion). Also, the economic reforms of the past decade have put Nigeria back on track towards achieving its full economic potential. Nigerian GDP at purchasing power parity (PPP) has almost tripled from $\$ 170$ billion in 2000 to $\$ 451$ billion in 2012.

However, the productive base of the Nigerian economy remains weak, narrow and externally-oriented with primary production activities of mining and quarrying (including crude oil and gas) accounting for about $13.82 \%$ and over 80 percent of government revenues. In contrast, secondary activities comprising manufacturing and agriculture, which traditionally have greater potential for broadening the productive base of the economy and generating sustainable foreign exchange earnings and government revenues account for $29.41 \%$ percent of gross output. Services or tertiary activities which depend on wealth generated by the productive sectors for their operations comprise about $49.1 \%$ percent of gross output.

With the new GDP results, agriculture now accounts for $21.5 \%$ of GDP and the manufacturing sector $7.91 \%$ of GDP (Table 1). The share of the manufacturing sector is low given it's strategic importance in the quest for Nigeria to become among the top 20 economies in the world by the year 2020. The manufacturing sector is projected to 
contribute significantly to GDP with a manufacturing value added of not less than 40 percent in the vision 20:2020 document. This is because the achievement of Nigeria's Vision requires a vibrant manufacturing sector that is able to cope with the dynamic challenges of an increasingly globalised world. Similar strategic economic plan such as The Transformation Agenda, the Seven Point Agenda, the industrial Revolution Plan, and the new Nigerian agriculture policy recognized the importance of the real sector as a key driver of economic development.

Table 1: Growth and Composition of the Nigeria Gross Domestic Product (2013)

\begin{tabular}{|c|c|c|c|c|c|c|}
\hline & \multicolumn{3}{|c|}{$\begin{array}{l}\text { Growth of the Gross Domestic } \\
\text { Product }(\%)\end{array}$} & \multicolumn{3}{|c|}{$\begin{array}{l}\text { Composition of Sectors in the } \\
\text { Gross Domestic Product (\%) }\end{array}$} \\
\hline Sector & 2011 & 2012 & 2013 & 2011 & 2012 & 2013 \\
\hline Agriculture & 3.45 & 2.76 & 1.62 & 23.59 & 22.73 & 21.50 \\
\hline Mining And Quarrying & 3.51 & -2.15 & 5.30 & 15.36 & 14.09 & 13.82 \\
\hline Manufacturing & 10.62 & 13.77 & 14.65 & 6.95 & 7.41 & 7.91 \\
\hline $\begin{array}{l}\text { Electricity. Gas .Steam and Aircond } \\
\text { Supply }\end{array}$ & 39.95 & 13.23 & 12.83 & 0.77 & 0.82 & 0.86 \\
\hline $\begin{array}{l}\text { Water Supply. Sewerage, Waste Mgt\& } \\
\text { Remedy }\end{array}$ & 12.01 & 17.54 & 15.71 & 0.14 & 0.16 & 0.17 \\
\hline Construction & 12.65 & 15.30 & 16.00 & 3.11 & 3.36 & 3.63 \\
\hline Trade & -2.10 & 18.40 & 7.80 & 15.31 & 17.00 & 17.06 \\
\hline Accommodation And Food Services & 8.86 & 7.73 & 9.32 & 0.47 & 0.47 & 0.48 \\
\hline Transportation And Storage & -2.32 & 3.13 & 5.09 & 1.19 & 1.15 & 1.13 \\
\hline Information And Communication & 9.84 & 5.14 & 9.35 & 11.49 & 11.33 & 11.54 \\
\hline Arts. Entertainment And Recreation & 26.65 & 17.99 & 19.65 & 0.07 & 0.08 & 0.08 \\
\hline Financial And Insurance & 18.79 & 16.03 & 21.00 & 2.59 & 2.82 & 3.18 \\
\hline $\begin{array}{l}\text { Professional, Scientific \& Technical } \\
\text { Services }\end{array}$ & 6.47 & 2.54 & 7.19 & 3.20 & 3.08 & 3.07 \\
\hline Administrative \& Support Services & 6.01 & 1.52 & 6.42 & 0.02 & 0.02 & 0.02 \\
\hline Public Administration & 5.56 & 1.68 & 6.28 & 3.70 & 3.53 & 3.49 \\
\hline Education & 14.33 & 5.87 & 9.40 & 1.66 & 1.65 & 1.68 \\
\hline Human Health And Social Services & 10.3 & 3.03 & 6.27 & 1.08 & 1.05 & 1.04 \\
\hline Other Services & 6.07 & 3.14 & 7.30 & 1.68 & 1.62 & 1.62 \\
\hline Total Gross Domestic Product & 5.09 & 6.66 & 7.41 & & & \\
\hline
\end{tabular}

Source: Authors' computation from Statistics Obtained from the National Bureau of Statistics

An examination of the top ten firms in the Nigerian stock market revealed the dominance of the Nigerian banking sector in contrast to the current long term vision where the real sector should dominate. This is also in contrast to other economies where the real sector firms dominate the stock market. Table 2 presents the top ten stocks across some selected economies. In th se of South Africa, the Standard Bank Group is the tenth most capitalized company in South Africa while banks occupied the fourth and sixth position in 
the case of Chile. Brazil however has the banks occupying the second and third position in the ranking of companies listed-on the stock exchange. In the case of Nigeria, banking firms are ranked fourth, fifth, sixth and tenth respectively. A close observation of the nature of firms revealed that the top three firms in Nigeria are in construction materials, beverages, and consumer goods. There are no intermediate and heavy manufacturing firms listed among the top ten firms. An ideal situation would have been for firms that produce automobiles, petrochemicals and other heavy industrial activities to be listed as the top ten firms in Nigeria. These have implications for achieving real sector growth for the Nigerian economy.

The real sector is the foundation of the modern economy and of nations' power, as it is the engine of growth and the fundamental base for economic health and security. Indeed, it is the source of strength of any economy and a key tool of modernization. If Nigeria is to join the league of developed nations worldwide, emphasis must be placed on the manufacturing sector harnessing Nigeria's sizeable domestic market and abundant resources to ensure a steady supply of products that are vital to the nation and the economy as whole. The real sector is the driver, mover and core of industrialization of the fully industrialized, leading economies of the world.

In order to achieve the long term vision for the real sector, the Nigerian banking industry has a vital role to play in these plans. This role is performed through the process of channeling funds in the form of credit or loan for investment to those economic agents who need them and can put them into the most productive use. It connects the surplus and deficit agents: channeling funds between lenders and borrowers. Thus, credit which is defined in this context, as the link through which resources are transferred for capital formation, facilitates investment which leads to economic growth. The impact of the delivery of these financial services in the form of capital to the producers is felt both in the short-run and in the long-run. The real sectors rely on the banking sector for the provision of required funds for investment purposes. It is therefore assumed that an increase in the bank lending to the real sectors will increase the productive activity of the sectors. The ineffective intermediation role of the banks will not enhance real sector performance and can affect future economic development of the country. This will therefore not enhance the desired economic structure that the Vision 20:2020 sought to achieve. 
Table 2: Top Ten Companies in South Africa, Chile, South Korea and Brazil 
Banking Sector Performance and the Real Sector in Nigeria

Banking sector activities are driven by the mobilization of deposits and granting of loans and advances in the economy. Deposit liabilities can be categorized as private and government. Components of private deposits include: demand, time, savings and foreign currency deposits. The analysis of deposits component revealed that over time the demand deposit overwhelms other categories of deposit. In terms of growth rate, time deposit has grown faster than the savings deposit, and in 2009, foreign currency deposits exceeded savings deposit (Table 3). The variation in deposits structure, therefore, shows that the Nigeria economy remains cash dependent, due to predominance of demand deposits and dwindling performance of the savings deposits. The foreign currency deposits have also become very important, suggesting improvement in Nigeria's export of banking services.

In addition, the total assets of Nigerian banks have increased over time. It increased from N235.8 million in 1960 to N17,331.6 billion in 2010. This implies that the monetary worth of the banks increased over time. The increased assets value of the banks implies that they either acquired more shareholdings or they recorded more plough back profits which are used to acquire more tangible and intangible assets needed for their operation. These indicators implied that the banking sector in Nigeria has grown in terms of deposits and assets.

Table 3: Structure of Banks Deposits and Total Assets ( $\mathrm{N}^{1}$ Million) 2000-2010

\begin{tabular}{|l|l|l|l|l|l|}
\hline & $\begin{array}{l}\text { Demand } \\
\text { Deposits }\end{array}$ & $\begin{array}{l}\text { Time } \\
\text { Deposits }\end{array}$ & $\begin{array}{l}\text { Saving } \\
\text { Deposits }\end{array}$ & $\begin{array}{l}\text { Foreign Currency } \\
\text { Deposits }\end{array}$ & Total Assets \\
\hline 2000 & 345001.4 & 154406.0 & 164624.2 & 38072.9 & 1568839 \\
\hline 2001 & 448021.4 & 235453.7 & 216509.4 & 47198.4 & 2247040 \\
\hline 2002 & 503870.4 & 300140.1 & 244064.1 & 109037.0 & 2766880 \\
\hline 2003 & 577663.7 & 324676.4 & 312368.9 & 122587.2 & 3047856 \\
\hline 2004 & 728552.0 & 401080.6 & 359311.2 & 172538.3 & 3753278 \\
\hline 2006 & 1497903.7 & 852357.9 & 592514.8 & 302380.0 & 4515118 \\
\hline 2007 & 2307916.2 & 1465281.5 & 753868.8 & 474404.1 & 7172932 \\
\hline 2008 & 3650643.9 & 2293605.8 & 1091812.2 & 924105.1 & 10981694 \\
\hline 2009 & 3386526.5 & 3147266.3 & 1171917.8 & 1444327.1 & 15919560 \\
\hline 2010 & 3830282.0 & 2858793.6 & 1589175.4 & 1506291.5 & 17522858 \\
\hline 2011 & 4920850.2 & $! 2704981.1$ & 1861410.9 & 1965520.1 & 17331559 \\
\hline 2012 & 5069992.0 & 3317280.9 & 2017845.2 & 2726978.5 & 19396633 \\
\hline 2013 & 5160846.5 & 2839355.3 & 2365032.5 & 3402223.6 & 21288144 \\
\hline
\end{tabular}

Source: CBN Statistical Bulletin, 2013.

54 Annals of the Social Science Academy of Nigeria, No 20, 2015 
Conversely, the mobilized deposits are not being channeled into the activities pf the real sector. The broad objectives of credit policies in Nigeria, over the years, have been the enhancement of credit availability, reduction of cost and improvement of access to credit to the private sector, and the stimulation of growth in the real sectors of the economy. Accordingly, credit guidelines were designed to ensure that the financial ${ }^{1}$ needs of the real sectors of the economy, especially the small and medium enterprises, (SMEs) are effectively and efficiently met. Banks were, therefore, required to pa\}' greater attention to the prescribed aggregate and sectoral allocation of their loans and advances to enhance the attainment of the long term vision and objectives of the government. However, this is not the situation in the case of Nigeria.

Table 4 underscores the nature of the problem. Sectors such as agriculture and manufacturing are getting decreasing shares of the total loans and advances of commercial banks in Nigeria. The percentage share of agricultural sector loans and advances declined from $8.07 \%$ in 2000 to $2.46 \%$ in 2005 and $1.67 \%$ in 2010 . Similarly, the credit allocation of the commercial banks to manufacturing sector fell from $27.6 \%$ in 2000 to $17.8 \%$ in 2005 and 14.4 in 2011. Ironically, these are the productive sectors that the country looks up to for achieving its vision of growth and economic development.

In contrast, commercial banks' credit to the mining sector that used to be low in the 1990s has increased in the recent years. It increased from 1.4 percent in 1990 to 15.0 percent in 2010 (the highest out of all the sectors). Beginning from 2008, the sectors that received significant share of credit allocation are transport and communication, financial institutions, government and import.

These findings are mirrored by the over-dependence on the oil sector for foreign exchange earnings and government revenue, despite its minute backward and forward linkages with the economy. For example, between 2005 and 2010, the agricultural sector attracted on average 2.0 per cent of the total credit to the economy in contrast to its average contribution of 42.2 per cent to the GDP over the same period. This suggests that despite the increased deposits and asset base of banks as a result of the recapitalization policy, the real sectors suffered access to commercial banks' credit. The low credit to the sectors by the commercial banks has been attributed to a number of reasons, notable among which are the inherent risk and insufficient collateral, poor managerial ability, low ability to repay, unfavourable growth prospects in the sectors, and the perception of the sector as non-strategic to the business models of the commercial banks. Hence, as long as these concerns linger, the issue of financing the real sectors in Nigeria would require more than just providing funds to the sectors. 


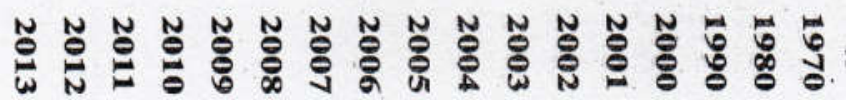

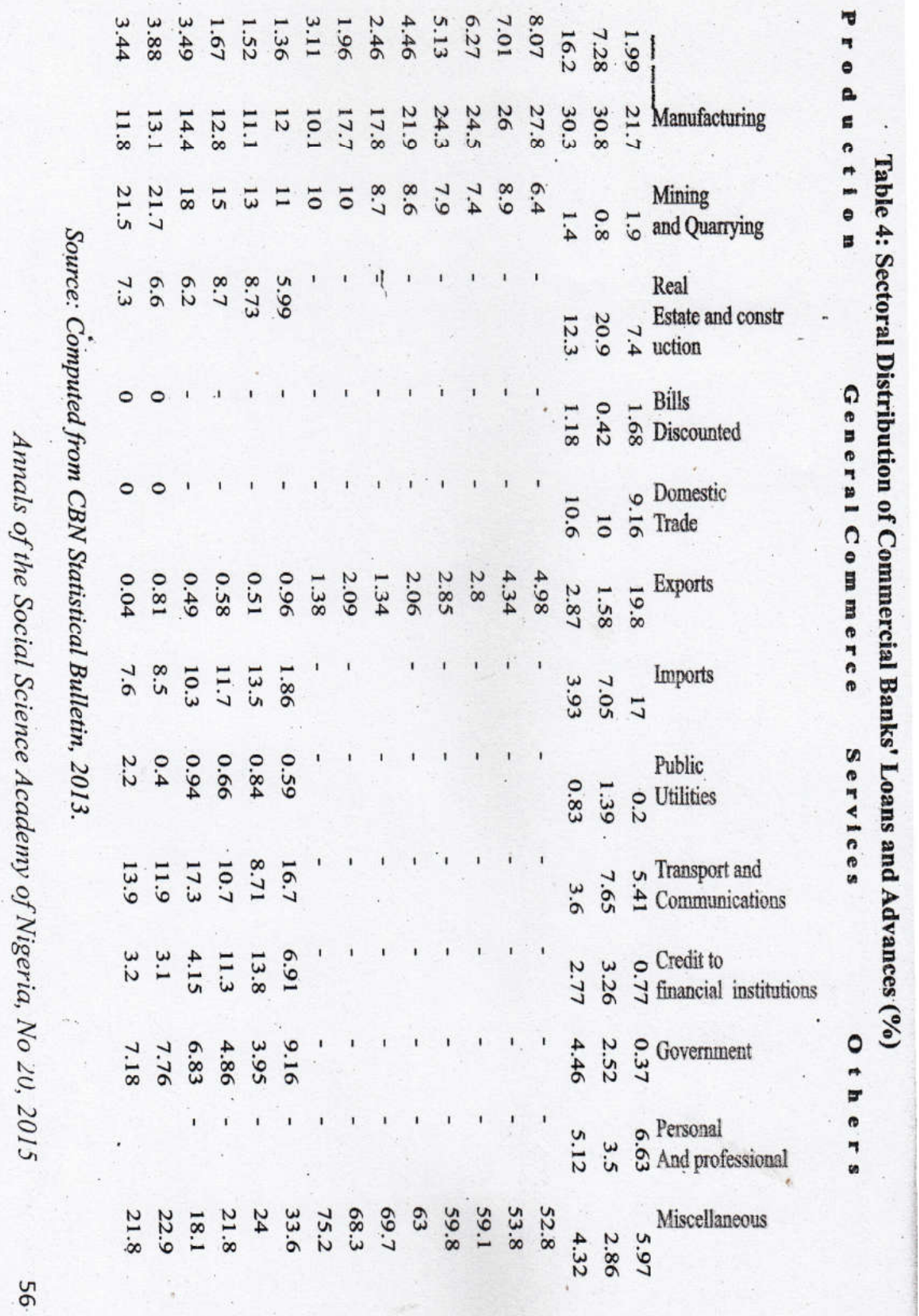


Anyanwu (2010) noted that in credit packaging, bank treasurers evaluate the safety of their funds, the liquidity of the balance sheets and the profitability of proposed ventures. Safety has more weight the smaller the asset base, while the need to ensure liquidity depends on the customer base and the frequency of transactions. Profitability compensates shareholders and guarantees going concern for the bank. Since the liberalization of the credit market in Nigeria under SAP, the status of preferred sector was stripped off the real sectors and so the compulsory funding from banks dried up. Furthermore, the market-determined interest rates have tended to exclude the real sectors, especially, agriculture, from the credit market. An assessment of the National Accounts of Nigeria indicates that the real sectors contribute over 60.0 per cent to the gross domestic product (GDP), but attracts only about 40.0 per cent of total credit (Anyanwu. 2010).

The small scale enterprises sub-sector (SSEs) is a segment of the private sector that is expected to be given priority in terms of allocation of credit in the economy. This is because of its resilience and capacity to generate increased employment and output. Unfortunately, commercial banks credit to the SSEs has been on a downward trend since 1992 as shown in Figure 1. The percentage fell precipitously from around 49\% in 1992 to about $0.16 \%$ in 2010 . It should be recalled that since the initial rule that made it mandatory for banks to grant a minimum of $20 \%$ of their credit to small scale enterprises was abolished in 1996. Nigerian banks have paid very little attention to this sector.

\section{Figure 1: Commercial Banks Loans To Small Scale Enterprises as Percentage of Total Credit (\%)}

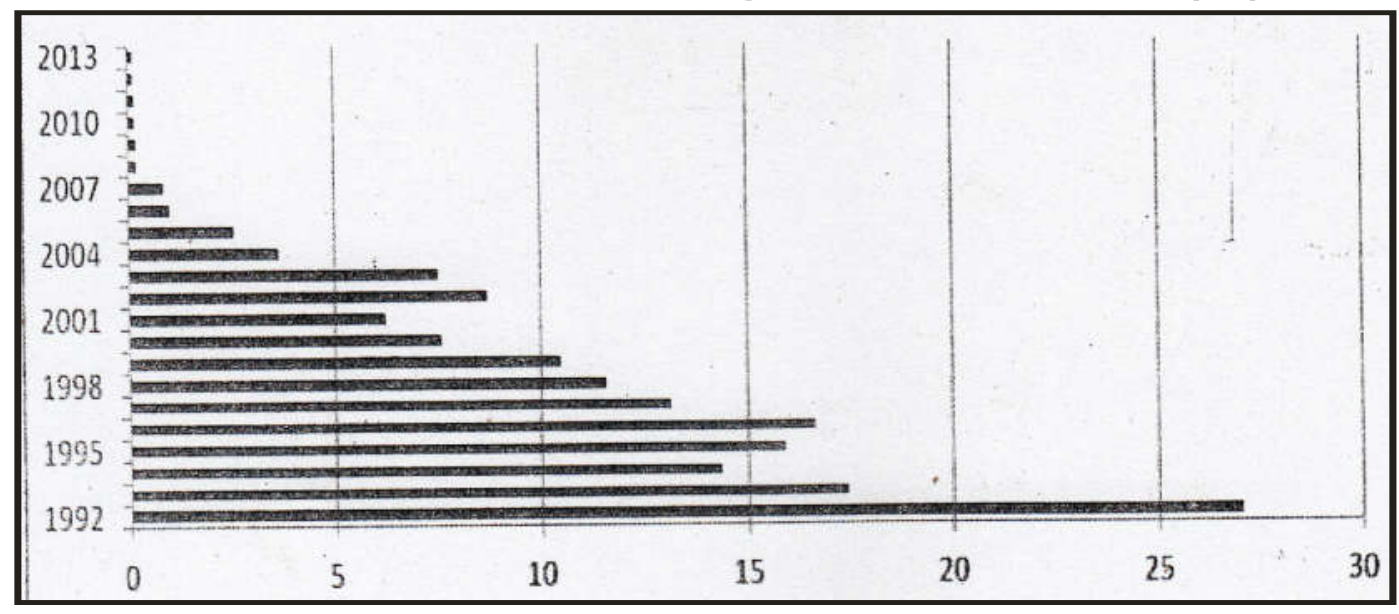

Source: CBN Statistical Bulletin, $20 \mathrm{~J} 3$

This finding is important given that most Nigerian enterprises in the real sector are still of micro and small scale (NBS-SMEDAN, 2012). 
However, a close of examination of the activities of the commercial banks with respect to the level of deposits mobilized is quite revealing. Total federal government deposit with commercial banks increased from J473.8 billion in 2000 to W922.1 billiorf in 2012. When the deposits of the other tiers of government are added, the value rose from 14119.7 billion in 2000 to 141.81 trillion in 2012 (Table 5). Although private sector deposits represented the bulk of commercial bank deposits in this period, the magnitude of government deposit was also substantial. It was also gaining relative importance in terms of its share in total deposits. The share of total government deposit increased from $15.43 \%$ in 2000 to the peak percentage point of $23.06 \%$ in 2011 . This finding therefore identifies government as the largest single source of inputs (deposits) to commercial banks in Nigeria.

Table 5: Structure of Total Government and Private Deposit. 2000-2012

\begin{tabular}{|c|c|c|c|c|c|c|c|}
\hline Year & $\begin{array}{l}\text { Total Deposits } \\
\text { (N' Million) }\end{array}$ & $\begin{array}{c}\text { Federal Government } \\
\text { Deposit } \\
\text { (N' Million) }\end{array}$ & $\begin{array}{c}\text { Total } \\
\text { Government } \\
\text { Deposit } \\
\text { (N'Million) }\end{array}$ & $\begin{array}{c}\text { Total Private } \\
\text { Deposit } \\
\text { (N' Mrillion) }\end{array}$ & $\begin{array}{c}\text { Federal Government } \\
\text { Deposit in Total } \\
\text { Deposit } \\
(\%)\end{array}$ & $\begin{array}{c}\text { Total } \\
\text { Government } \\
\text { Deposit in Total } \\
\text { Deposit } \\
(\%)\end{array}$ & $\begin{array}{l}\text { Private } \\
\text { Deposit in } \\
\text { Total } \\
\text { Deposit } \\
(\%)\end{array}$ \\
\hline 2000 & $775,932.30$ & $73,827.80$ & $119,760.10$ & $618,099.30$ & 9.31 & 15.43 & 79.66 \\
\hline 2001 & $975,525.30$ & $28,342.40$ & $55,668.20$ & $872,658.70$ & 2.91 & 5.71 & 89.46 \\
\hline 2002 & $1,209,747.30$ & $52,635.70$ & $100,089.00$ & $1,000,621.30$ & 4.35 & 8.27 & $\$ 2.71$ \\
\hline 2003 & $1,417,060.00$ & $79,763.80$ & $123,699.40$ & $1,170,773.40$ & 5.63 & 8.73 & 82.62 \\
\hline 2004. & $1,741,587.60$ & $80,105.50$ & $139,656.40$ & $1,429,392.90$ & 4.60 & 8.02 & 82.07 \\
\hline 2005 & $2,131,090.47$ & $95,000.64$ & $168,680.81$ & $1,773,898.57$ & 4.46 & 7.92 & 83.24 \\
\hline 2006 & $3,355,097.63$ & $109,941.14$ & $215,892.87$ & $2,836,824,71$ & 3.28 & 6.43 & 84.55 \\
\hline 2007 & $5,211,2,35.15$ & $209,764.62$ & $357,030.01$ & $4,379,801.09$ & 4.03 & 6.85 & 84.05 \\
\hline 2008 & $8,252,891.78$ & $292,724.84$ & $699,070.07$ & $6,629,716.67$ & 3.55 & 8.47 & 80.33 \\
\hline 2009 & $9,601,809.65$ & $451,771,98$ & $903,338.61$ & $7,254,143.96$ & 4.71 & 9.41 & 73.55 \\
\hline 2010 & $10,610,171.91$ & $825,629.50$ & $1,427,660.10$ & $7,676,220.29$ & 7.78 & 13.46 & 72.35 \\
\hline 2011 & $12,131,470.43$ & $678,707.18$ & $2,797,843.45$ & $7,368,106,02$ & 5.59 & 23.06 & 60.74 \\
\hline 2012 & $13,309,259,55$ & $922,189.27$ & $1,806,940.55$ & $8,920,978.56$ & 6.93 & 13.58 & 67.03 \\
\hline
\end{tabular}

Source: CBN Statistical Bulletin. 2010and20I2

This therefore raises the question on what commercial banks do with government idle funds in creating assets, treasury operations or even financing trade. It is found that these banks mainly use government funds to purchase and receive interests on government short term securities rather than lending to the private sector. For example, the share of government in the loans and advances ranges between 15 and 20 percent amidst some fluctuations further reinforcing the argument that government is the major player in the financial sector both as a saver and also as a borrower (Table 6). These 
loans and advances are supposed to be directed to the real sector of the Nigerian economy.

Commercial banks in Nigeria have a higher preference for the government treasury bills which is mainly risk-free. Beginning from the year 1999, commercial banks have consistently increased their holdings of Treasury Bills, The percentage holding was about $34.1 \%$ in 2001 and $52.22 \%$ in 2003 and stood at $70.5 \%$ in 2009 (Table 7). These funds represent the bulk of the credit that should have gone to the real sector of the economy. Hence, borrowing by the government has the tendency to crowd out private investment and constitutes an additional $\cos ^{1}$; to the economy.

Table 6: Use of Funds by Commercial Banks (NMillion)

\begin{tabular}{|l|l|l|l|l|}
\hline Period & $\begin{array}{l}\text { Total Claims on } \\
\text { Government }\end{array}$ & $\begin{array}{c}\text { Total Claims on } \\
\text { Private Sector } \\
\text { (N'Million) }\end{array}$ & $\begin{array}{c}\text { Total Loan and } \\
\text { Advances }\end{array}$ & $\begin{array}{c}\text { \% of } \\
\text { Government } \\
\text { Loans and } \\
\text { Advance } \\
\text { la Total }\end{array}$ \\
\hline 2000 & $285,630.7$ & $480,017.20$ & $1,051,278.6$ & 27.16984 \\
\hline 2001 & $235,066.9$ & $817,689.80$ & $1,287,823.6$ & 18.25304 \\
\hline 2002 & $484,848.3$ & $931,137.50$ & $1,900,834.1$ & 25.50713 \\
\hline 2003 & $398,439.4$ & $1,182,964.10$ & $1,979,842.9$ & 20.1248 \\
\hline 2004 & $633,707.1$ & $1,494,610.90$, & $2,762,025.1$ & 22.94357 \\
\hline 2005 & $684,374.8$ & $1,936,619.82$ & $3,307,369.4$ & 20,72266 \\
\hline 2006 & $1,074,182.8$ & $2,528,637.00$ & $4,677,002.6$ & $22 \sim 96733$ \\
\hline 2007 & $2,048,161.4$ & $4,732,942.12$ & $8,829,264.8$ & 23,19742 \\
\hline 2008 & $1,866,915.0$ & $7,649,634.97$ & $11,383,465.0$ & 16,40024 \\
\hline 2009 & $2,191,405.4$ & $9,357,552.41$ & $13,740,363.2$ & 15.94867 \\
\hline 2010 & $3,041,040.9$ & $8,828,363.23$ & $14,827,058.2$ & 20.51008 \\
\hline 2011 & $3,675, .650 .2$ & $9,101,227.14$ & $12,776,877,3$ & 28.76799 \\
\hline $2012 ;$ & $2,899,408.4$ & $9,775,077.05$ & $12,674,485.5$ & 22.87595 \\
\hline 2013 & $4,305,285.9$ & $10,766,951.89$ & $15,072,237.8$ & 28.56434 \\
\hline
\end{tabular}

Source: CBN Statistical Bulletin, 2013. 


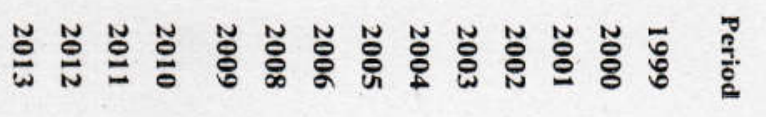

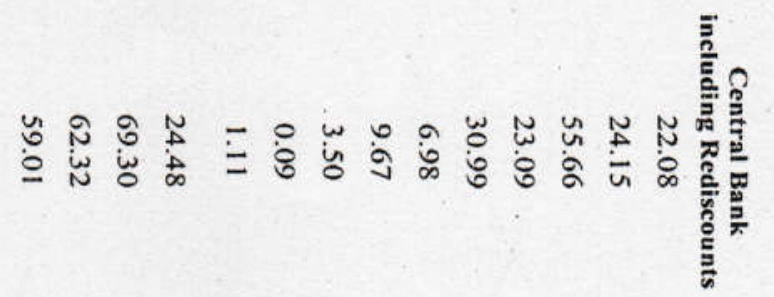

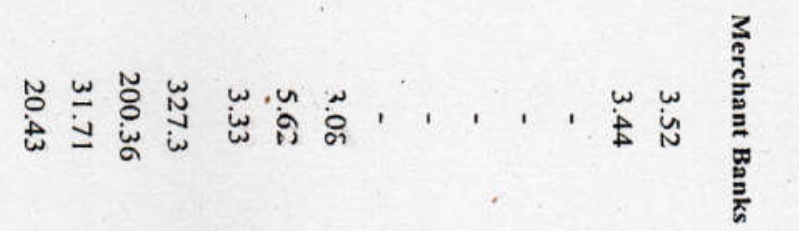

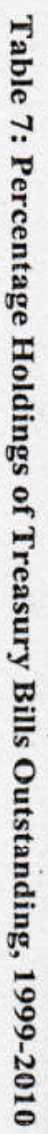

g 
A closer look at the components of the total assets of the commercial banks revealed that foreign assets dominates the total assets of commercial banks followed by claims on Federal Government and unclassified assets. Claims on non-financial public enterprises, claims on (non-financial) private sector and claims on financial institutions have the least shares of commercial banks total assets (Table 8). With respect to foreign assets, demand deposits at foreign banks take the largest percentage while treasury bills, treasury bills rediscounts, treasury bond dominate the claims on the Federal Government. Evidently, the bulk of the commercial banks assets are in components that do not have direct link with the real sectors of the Nigerian economy despite the huge growth in total assets.

This model of banking can be situated in the context of the lazy bank hypothesis. Specifically, the 'lazy bank' (arm-chair banking) syndrome claim is that government borrowing will create moral hazard and discourage banks from seeking profitable investment opportunity and lending to the riskier private real sector. This is evidence that has been found in many developing countries. The major symptoms of the above problem is that, in such an economy, banks usually maintain a high ratio of liquid asset and are reluctant to lend to the productive sector which is perceptively considered very risky. These problems are clearly evident in the case of Nigeria as revealed in the preceding section. Studies have shown that entrepreneurs in the country lack access to low-interest credit facility and this has immensely limited their growth potentials and that of the economy. Equally, banks in the country maintain a very high liquid-asset ratio.

However, the avenue for the lazy banking hypothesis (arm-chair banking) is closing with the likely introduction of the treasury single account (TSA). Given the commercial banks access to MDAs' funds, two questions often arise: what is the cost of these funds to the government and to the banks and how do banks utilize these funds in order to redeem the liability as and when due while also making enough to cover their own cost of funds? In terms of the costs, the maintenance of idle balances by MDAs at commercial banks has been shown to impose unnecessary costs of borrowing on the government. Being unaware of these idle balances, governments often raise funds to cover perceived cash shortages at a cost. Equally, when the idle funds generate excess liquidity, extra costs are incurred by the Central Bank in mopping them up through its Open Market Operations especially in trying to control easy money and inflation. 
Hence, attempts to avoid these costs have led to the need for the adoption of a Treasury Single Account (TSA) system. It will be used as a tool for the government to plan and control its issuance of debt instruments and lending in the context of its overall cash flow. Although the systems operated vary across countries, it is common that MDAs are expected to accurately forecast their cash flows and their accounts have to be swept into a common treasury account at a stipulated period, usually daily.

Another pointer to the closing up of the lazy banking hypothesis is the different attempt by government to withdraw its deposits from the commercial banks. In June 1,1989, the Federal Government withdrew its deposits from the commercial banks to the Central Bank of Nigeria (CBN). A total sum of about N13 billion was to be moved from commercial banks to the CBN, which consisted of deposits from government parastatals with various commercial banks in Nigeria (Dogarawa, 2012). The consequences of this sudden policy were the short-run shocks and distortions created in the banking system as well as the systemic squeeze in bank credits which inadvertently affected the very sectors that government wanted to grow. A similar but an unsuccessful attempt was made in 1999. The CBN recently increased the cash reserve ratio (CRR), which is the required cash banks are expected to keep with the apex bank, from $50 \%$ to $75 \%$ for public funds while still maintaining $30 \%$ and $12 \%$ liquidity ratio and CRR respectively. The new monetary policy mandates banks to keep $75 \%$ of public sector funds, which comprise deposits of all tiers of government as well as ministries, departments and agencies (MDAs), with the CBN. The withdrawal of these funds has therefore tightened banks' liquidity.

In sum, the over dependence of commercial banks on public sector funds is gradually fading out. The perceived apathy of some commercial banks towards small savers in the country as well as the declining credit to small businesses in the country has been largely attributed to the amount of returns the financial institutions get from essentially trading with public sector funds. Therefore, the trend of monetary policy is gradually signaling the end of cheap money for banks. On the other hand, it has exposed the shallowness and fragility of the banking system. This was evident in the fact that the withdrawal of about N1.2 trillion from the system while implementing the policy, led to an 80 percent increase in the range of money market rates (Chima, 2013). Thus, a proper management of government cash flow may release some funds to the productive sector and reduce its tendency to be crowded-out.

Nonetheless, an overriding feature of the Nigerian banking industry is the high lending rate which is another significant reason why the real sector cannot obtain adequate credit for expansion despite the set of policy reforms undertaken in the sector. The spread between the savings and the lending rate was not pronounced prior to 1986 when the economy was liberalized. Available statistics revealed that the lowest spread of 2.25 was recorded in 1985. Thereafter, the spread between the two rates started widening as a result of the interest rate deregulation policy embarked upon from 1986 onwards. As highlighted in Figure 2, the lending rates from commercial banks are well above 20\% 
between 1989 and 2004 as a result of the liberalization policy embarked on during the period. This sometimes goes as high as about 35\%. The lending rate averaged $18.81 \%$ between 2005 and 2008 due to the bank consolidation exercise of the period (Figure 2). The rate again resumed an upward trend in 2009 as the second part of the bank consolidation exercise took-off. This is in sharp contrast with the deposit rate that is very low and declining. This huge difference has been used to justify why banks are often declaring large profits but sectors like manufacturing and agriculture are managing to survive in the country.

Figure 2: Weighted Average Deposit and Lending Rates of Commercial Banks

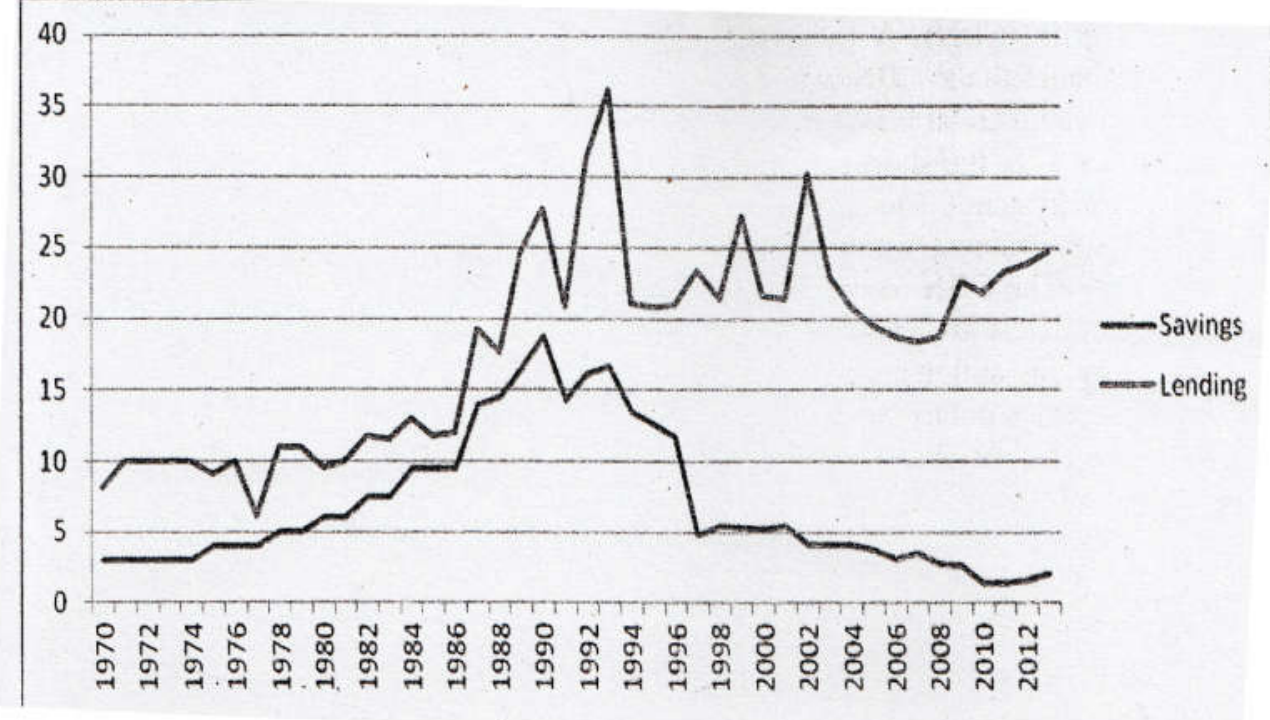

Source: CBN Statistical Bulletin, 2013

Arguments also subsist on the level of hidden charges that banks usually placed on their loans. Charges such as valuation of collaterals, evaluation of feasibility reports and any other technical support services are charged as part of the fees for loans to be advanced to the private sector. The end result therefore is that the borrower ends up paying much more than the interest rate charges on the loan. This practice persists in the sector despite the CBN directive on excess charges. Another dominant feature of the banking industry is the high percentage of non-performing loans. A higher percent of such loans shows that banks have difficulty collecting interest and principal on their loans. This may lead to less profit for the banks in Nigeria and, possibly, bank closures. The average value of the banks nonperforming loans to total gross loans in Nigeria between 2000 and 2011 was 18.1 percent with a minimum of 7.2 percent in 2008 and a maximum of 36.1 percent in 200i (Figure 3). In addition, a comparison of this variable with other developed economic highlights the precarious state of the Nigerian situation (Figure 4). The huge non performing loan recorded in 2009 was a result of commercial banks' huge exposures $t$ oil/gas and margin loans, which were largely non-performing. The huge NPL in this period led to a near system collapse of the banking sector which possibly could have been avoided if the bulk of the lending had gone to the productive

64 Annals of the Social Science Academy of Nigeria, No 20, 2015 
sector of the economy. According to CBN (2009) other factors that caused the crisis was the recall of foreign credit lines by correspondent banks, withdrawal of foreign portfolio investments from the system and the absence of a robust liquidity risk management framework, [See Ajakaiye and Telia (2014) and Ajakaiye and Fakiyesi (2009) for further elaborations on these and related issues]. To address the problem, the CBN and the Federal Ministry of Finance spearheaded the establishment of the Asset Management Corporation of. Nigeria (AMCON) to purchase non-performing loans from deposit money banks and recapitalize the affected banks. Consequently, AMCON injected a capital of about N678bn to the 3 nationalized banks to assure them of the safety of depositors' funds.

Figure 3: Ratio of Bank Nonperforming Loans to Total Loans (\%)

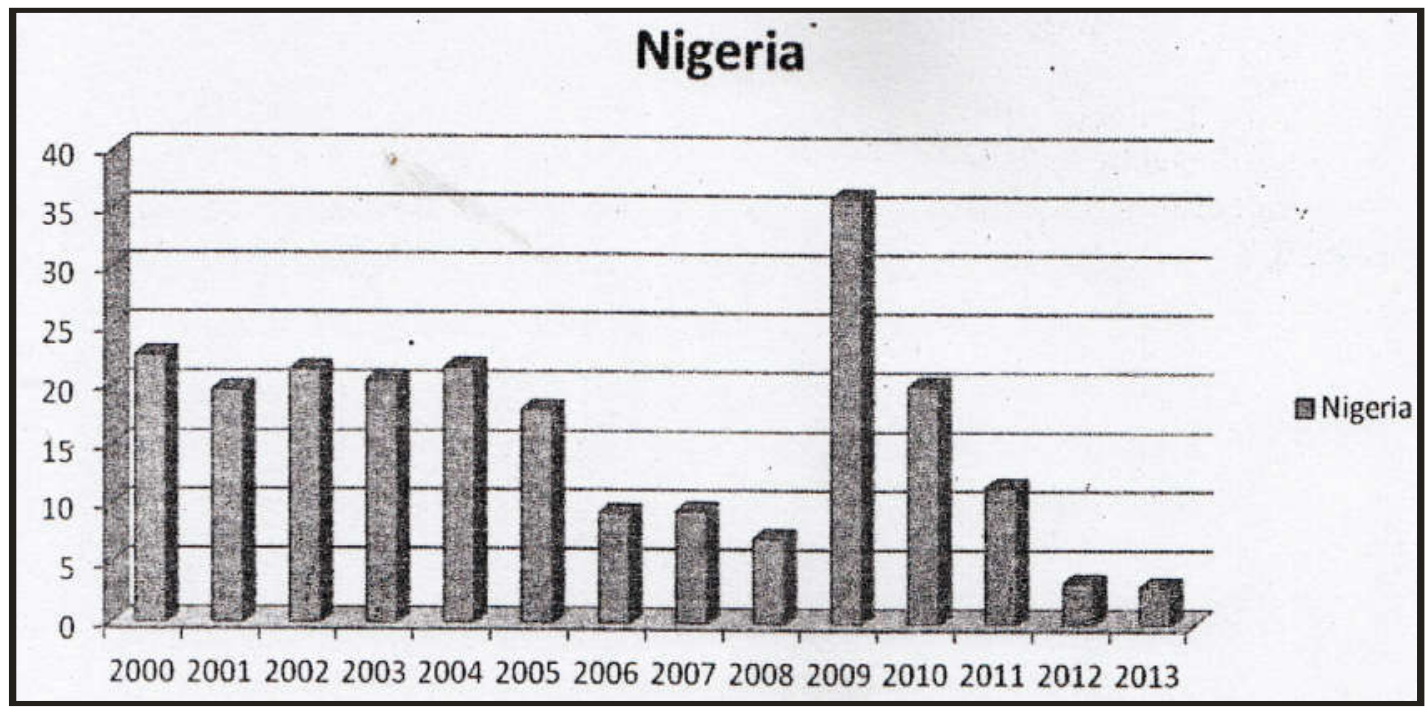

Source: World Bank World Development Indicators,

Figure 4: Comparison of Nigeria's Bank nonperforming loans to total gross loans (\%) with other countries.

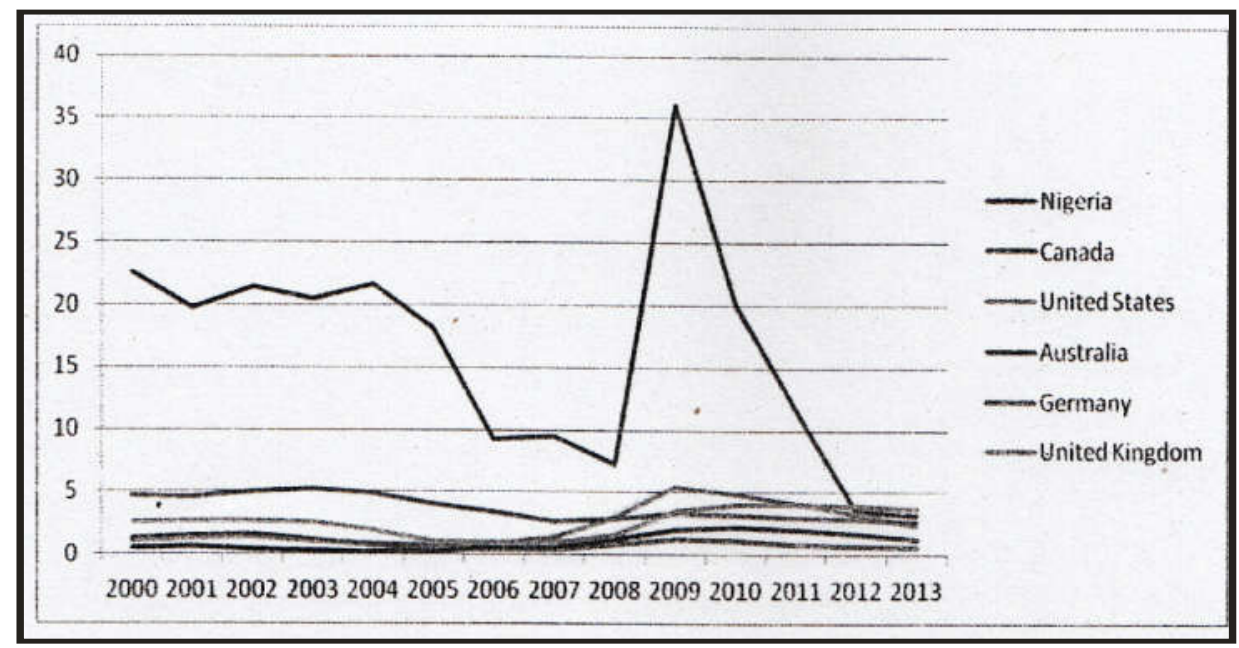

Source: World Bank World Development Indicators, 2014

Annals of the Social Science Academy of Nigeria, No 20, 2015 


\section{Going Forward: Future of Banking System in Economic Development in Nigeria}

The future of banking system impact on economic development in Nigeria will be shaped, in large part, by its ability to re-connect with the real sector of the economy. The financial system must be able to mobilize savings effectively from domestic and cross-border sources, towards meeting the large and diverse financing and investment needs of the real sector of the economy to advance economic development. The options for addressing the challenges of poor bank lending to the real sectors include:

- Discouraging Ann-chair Banking Business Model and Encouraging Promotional/Supportive Banking Business Model (Funding for Lending Approach)

To serve as a model in advancing credit to the productive sector, government can give conditions of lending to the real sector as the basis of being the custodian of its deposits. Guidelines on how to utilize the deposits can then be defined and agreed with the interested banks. Only the productive sectors will be beneficiaries of the loans and advances. With this scenario, commercial banks .will not be operating an arm chair banking model but will serve as a partner with the real sector agents (borrowers). Assistance will be offered by the banks in areas of feasibility studies, offering technical advice to the enterprises, and assisting in designing the framework for the financial flows among others. These measures are expected to reduce the inherent risks usually associated with the performance of the real sector of the economy. The banks therefore would have moved from the passive ami chair banking to active and effective intermediation.

AMCON should be made to underwrite any form of NPL arising from this process. However, such information will not be made available to the banks so that a repeat of the 2009 episode will not occur. The involvement of the banks in the activities of the enterprises will likely yield a better result than what the system is currently experiencing. Thus, the condition for holding government deposit is to be part of the new lending scheme for revitalizing the real sector. Effective regulations must, however, be in place to ensure total compliance with the scheme and any erring bank should thereafter be appropriately sanctioned.

\section{- Promoting Modified Collateral Bank Lending Model}

Collateral is central to the relationship between lenders and borrowers to the point that credit would not be extended in the absence of the right to repossess collateral. This view of collateral stems from the idea that moral hazard is the main problem in financial relationships between lenders and borrowers. Borrowers may have the incentive to use the money borrowed unproductively (e.g. finance their own consumption) or simply to hide the proceeds of the project from their creditors and default on their promises to repay (Manove and Padilla, 1999). The right to repossess collateral therefore gives lender an essential threat to ensure that borrowers will not behave in this way. An 
immediate implication of this view is that the stronger the protection that creditors obtain via collateral repossession, the more abundant and cheaper credit will be for entrepreneurs.

This conventional view of creditors' right neglects a number of reasons why lenders' unrestricted reliance on collateral might have a negative impact on credit-market efficiency. Banks may be better able than entrepreneurs to predict the performance of potential investment projects, and a high level of collateral will weaken a bank's incentive to do so. Banks that finance large numbers of investment projects in a specific sector of the economy are well placed to appraise the performance of those projects. Unlike individual entrepreneurs, they may have considerable experience with similar projects undertaken by a range of businesses. Banks often have access to valuable statistical information that is not readily obtained by entrepreneurs. Also, banks can be expected to have considerable familiarity with the economic features of their locality and general economic trends.

In markets with perfectly competitive banks and complete contracts, banks would offer to screen projects as a service to entrepreneurs, who would then bear the cost of screening which has implications for the total amount to be paid back. However, if the screening services of banks cannot be enforced by contract, banks that are highly protected by collateral may perform too little screening of the projects that they finance. Thus, the banks do little screening and tend to rely excessively on collateral repossession. In addition, entrepreneurs have complained that banks place too little weight on the future prospects of their company and too much on their ability to post personal assets, especially real estate, as collateral for the loan. There are also allegations that bankers' carelessly expand credit to entrepreneurs who post collateral, only to regret later when massive defaults and declines in the value of posted collateral threatened the financial soundness of their own institutions.

To reduce the incidence, there is a need for banks to conduct project screening at no fees for the entrepreneurs and place more emphasis on project screening rather than collateral. This also serves as a basis for the introduction of the non-interest banking model that does not require collaterals from borrowers. Rather, its lending activities are carried out within the context of an agreed profit and loss sharing arrangements with the borrower.

- Establishing Sectoral/Specialized Development Banks to Complement Commercial Bank Lending and Securing Appropriate Maturity Profile of Loans to the Real Sectors

A financial system can influence the allocation of real resources between surplus and deficit units. In addition, a financial intermediating system can be used to channel financial resources to certain desired deficit units that are expected to use the resources for specific purposes, or the terms on which the financial resources are provided can be manipulated to influence the decisions of potential users. However, one of the 
constraints that prevent commercial banks from lending to the real sectors is loan/ deposit maturity mismatch profile of the banks. The deposits mobilized from the private sector in most of the cases, are usually short term while the credit line required by the real sector investors are long term. This therefore throws up a mismatch. As a result, there is a need to enhance the capacity of the financial sector to support the financing needs of real sector large-scale projects with long gestation periods. The provision of products with longer maturities will meet the longer-term investment demand of real sector institutional investors. The provision of long-term loans will assist the real sector to modernize production facilities and develop a new product or process. This is particularly important given the banks' limitation in extending loans to the real sector. This calls for the creation of well capitalized sectoral development banks that will complement commercial banks through well-structured loan syndication, for example. Such sectoral development banks should also have expertise in the technical, operational and business aspects of the sector and hence able and ready to provide these advisory support services to complement the financial services. It is pertinent'to recall that these were the attributes of the defunct Nigerian Industrial Development Bank (NIDB) which contributed to its huge success in initiating industrial development of Nigeria prior to 1986.

\section{- Encouraging Specialization of Bank Branches}

There is a need to shift from the current universal banking model to regional specialization of bank branches in Nigeria. Rather than make all the bank branches perform the same activities, bank branches across the country should be made to respond to the needs of the community where they are located. The characteristics of the local economy should determine the kind of expertise/services that the banks want to provide. For example, the City of Kano is known for agri-business/agro-processing activities and therefore the expertise of the bank branches in Kano must be tailored towards providing banking services that encourage the development of agribusiness network in Kano. Industry specific banking expertise can also be provided in Kaduna which is known for its booming textile industry, Port-Harcourt (oil and gas) and Ebonyi (rice industry). This will then give a re-direction of the present pattern of real sector growth in Nigeria.

\section{- Deepening and Institutionalizing the Special CBN Real Sector Financial Intervention Initiatives}

The CBN has commendably embarked on different types of initiatives to stimulate the real sector. Some of these initiatives include the Agricultural Credit Guarantee Scheme Fund (ACGSF), the Agricultural Credit Support Scheme (ACSS), The Commercial Agricultural Credit Scheme (CACS), the N200 Billion Refinancing/Restructuring of SME/Manufacturing Fund and the SME Credit Guarantee Scheme (SMECGS). These programmes .should be further deepened to enhance the access of real sector participants to the funds. Other initiatives such as Start-up Company Promotion Fund loans can also be instituted as part of the initiatives. This is because access to financing can be a critical issue for the real sector in their early years. This is a credit line that is extended to real 
sector firms who are just starting their businesses. This will be a good example of public sector/private sector cooperation to stimulate the performance of the rea sector. In order to institutionalize and sustain these and similar special intervention initiatives of the $\mathrm{CBN}$, they should be placed under the relevant sectoral development banks that are insulated from political interference and embedded as proposed earlier.

\section{» Strengthening the Established Credit Bureau}

The credit risk at the peak of the global financial crisis constituted a threat to the viability of the banking system. To "reduce the risks, the CBN established and licensed three private credit bureaus to complement the Credit Risk Management System (CRMS) of the $\mathrm{CBN}$, in order to improve the credit appraisal procedures of commercial banks, so as to strengthen their credit risk management processes. Real sector borrowers complain about complicated loan assessment and decision-making procedures of commercial banks. Commercial banks on the order hand place high priority on the creditworthiness of borrowers and their ability to repay loans. The operations and capacities of the credit bureaus should be strengthened to streamline the loan assessment procedures of the commercial banks. The enhancement of a model that evaluates the creditworthiness of potential borrowers would help commercial banks reduce the associated high risks and transaction costs. The activities of the credit bureaus should also be made to cover micro-enterprises as well as Small and Medium Enterprises (SMEs).

\section{Conclusion}

In sum, the banking sector has a future role to play in the economic development of Nigeria. If efficient intermediation is not carried out, if virtually all banks offer identical services and products, if new technology remains delayed, if all individuals do not have access to basic banking services - in other words if we stay as we are today - then our economy will not achieve anything close to its potential.

The role of banks as financial intermediaries has a major bearing on how efficiently the economy allocates its resources between competing uses. In considering efficiency, we are interested in whether lending activity helps resources flow to their best use or whether some sectors get too little or too much credit relative to what is needed for the economy to develop. We are also interested in whether lending and other financial activities are provided in a cost effective manner from the point of view of consumers, real sector investors and the degree to which the banks improve and innovate their financial products and services over time. All else equal, a well-managed bank acting prudently and operating in a reasonably competitive market will be making credit available at an appropriate price to creditworthy borrowers. This will aid the growth of the real sector and fast tracked the process of economic development.

In order to play an appropriate role in the economy, balancing its contribution to growth and to stability, the banking sector must be efficient and resilient. It must be efficient 
both in providing critical services at low cost and in responding flexibly to evolving demands. And it must be resilient to shocks that might interrupt its ability to provide core functions to the real sector of the economy.

\section{References}

Acaravci S. K., Ozturk, I. and Acaravci, A. (2009), Financial Development and Economic Growth: Literature Survey and Empirical evidence from Sub-Saharan African countries SAJEMS NS 12, No 111.

Afangideh, U.J. (ND), "Financial Development and Agricultural Investment in Nigeria: Historical Simulation Approach," Journal of Economic and Monetary Integration, 9(1): 74-96.

Ajakaiye O.and Telia, S. (2014), Financial Regulation in Low-Income Countries: Balancing Inclusive Growth with Financial Stability. The Nigerian Case (ODI Working Paper No. 409 (ODI, London).

Ajakaiye O. and Fakiyesi, T. (2009), Impact of Financial Crisis on Social Sectors of Nigeria (Global Financial Crisis Discussion Series Paper No. 8 (ODI, London).

Alade, S.O (2012), 'Quality Statistics in Banking Reforms for National Transformation'. CBN Journal of Applied Statistics, Vol.3 No.2.

Anyanwu, E. (2010), An Overview of Current Banking Sector Reforms and the Real Sector of the Nigerian Economy. CBN Economic and Financial Review, Volume 48/4. December.

Ayo, C.K, Adewoye, J.O, and Oni, A.A. (2010) 'The State of e-Banking Implementation in Nigeria: a Post-Consolidation Review'. Journal of Emerging Trends in Economics and Management Science 1.1:37-45.

Central Bank of Nigeria (2011), Statistical Bulletin. Central Bank of Nigeria, Abuja, Nigeria.

Chima, O. (2013), CRR: The Furore over Sterilisation of Public Sector Deposits in Banks. This Day Live. This Day Newspaper. August 14.

Dogarawa, L.B (2012), Impact of Government Withdrawal of Deposits from Commercial Banks in Nigeria. International Journal of Academic Research in Economics and Management Sciences. November, Vol. 1, No. 6.

Manove M and Padilla, A.J. (1999), Banking (Conservatively) with Optimists Rand Journal of Economics Vol. 30 No. 2:324-350. 
Mckinnon, R (1973), Money and Capital in Economic Development, Washington, DC: Brookings Institution.

NBS-SMEDAN, 2012, Nature and Number of Enterprises and Businesses, Source: 2010 National MSME Collaborative Survey.

Schumpeter, JA (1911) (translated 1934), The Theory of Economic Development, An inquiry into profits, capital, credit, interest and the business cycle. Oxford: Oxford University Press.

Shaw, ES (1973) Financial Deepening in Economic Development, New York: Oxford University Press.

Shittu, I.A. (2012) Financial Intermediation and Economic Growth in Nigeria, British Journal of Arts and Social Sciences, 4(2): 164-178. 